\title{
PERFORMANCE OF SUNFLOWER GENOTYPES IN NON-SALINE AND SALINE SOILS OF SOUTHERN BANGLADESH
}

\author{
M. K. Hossain, M. M. Islam, A. A. Mamun* and S. M. Abdullah Al Mamun \\ Agrotechnology Discipline, Khulna University, Khulna-9208, Bangladesh \\ ${ }^{*}$ Corresponding author, E-mail: mamungpbat@ku.ac.bd
}

(Received: 24 April 2017, Accepted: 7 June 2017)

Keywords: Non-saline soil, saline soil, sunflower genotype

\begin{abstract}
A research work was conducted with three sunflower genotypes to evaluate their performance in saline and non-saline soil after harvesting of T. Aman rice. The experiment was laid out in Randomized Complete Block Design (RCBD) with four replications. Three genotypes significantly influenced almost all the growth and yield parameters in both non-saline and saline field. Genotype Hysun-33 showed maximum germination percentage in non-saline soil but minimum in saline soil. Whereas, KUSL-1 performed the best in saline soil but worst in non-saline condition. Hysun-33 produced maximum leaf at flowering in both conditions but minimum leaf by BARI Sunflower-2 in saline soil and by KU-SL-1 in non-saline soil. In both non-saline and saline soils, plant height at flowering, head diameter, total seed head ${ }^{-1}$ and filled seed head $^{-1}$ were maximum for the genotype Hysun-33 and that of minimum for the genotype BARI Sunflower-2. Genotype KU-SL-1 showed maximum value for 1000seed weight followed by Hysun-33 in both saline and non-saline soils. In case of seed yield head ${ }^{-1}$, Hysun-33 performed best in saline soils but worst in non-saline soil. In non-saline soil, KU-SL-1 produced maximum seed yield head ${ }^{-1}$. Biomass at harvest, head diameter and number of filled seed head $^{-1}$ was well correlated with number of seed head and seed yield head ${ }^{-1}$. Thus genotype Hysun-33 may be considered as best for saline and KU-SL-1 for non-saline soil.
\end{abstract}

\section{Introduction}

Sunflower (Helianthus annuus L.) is an important oilseed crop in the world belongs to the Asteraceae family. Sunflower seeds are edible. It is a good source of protein, vitamins, calcium, nitrogen and iron. Its seed contains 40-45\% non-volatile oil and about 55\% linoleic acid. A proximate composition of sunflower seed is protein $20.8 \%$, lipid $54.8 \%$, carbohydrates $18.4 \%$, ash 3.9\% (Gopalan, 1982).

In Bangladesh, attempts of sunflower cultivation have been initiated and area of production is increasing. Now it is being grown in 16 districts of Bangladesh and the average production is about $1.2 \mathrm{t} \mathrm{ha}^{-1}$. There is a great scope for growing sunflower after harvest of T. Aman rice. Sunflower is grown on a wide range of soils and can tolerate a moderate $\mathrm{pH}$ and some salinity which is one of the main limiting factors of crop production (Chapman and Carter, 2000). In south-western Khulna region of Bangladesh, maximum agricultural lands are usually monocropped with T. Aman rice. In late December to mid January, when the rice is harvested, there remains a little chance of growing another crop because soil still remains in high moisture condition that limit tillage operation. When the soil becomes suitable for tillage then the level of soil salinity starts to increase. This situation prevails in all over the coastal region. Sunflower has been proved to respond well in minimum tillage system (dibbling method). It is considered as moderately salt and drought tolerant crop, and also a short durated crop (Chapman et al., 
1993). So, after harvesting of T. Aman rice, sunflower seeds can be sown in dibbling method in the month of January thus residual moisture can be exploited. From mid March usually soil salinity start to increase, when vegetative growth of sunflower attains in good condition.

In Bangladesh, several sunflower varieties have been developed by BARI and many have been introduced by some non-government organizations. The suitability test of the varieties for the coastal region is important for improving sunflower productivity. Therefore, a research was undertaken to evaluate the performance of three sunflower genotypes in non-saline and saline soils of southern region of Bangladesh.

\section{Materials and Methods}

The experiments were conducted at two locations, situated in the Low High Ganges River Floodplain Agro-Ecological Zone (AEZ-12), non-saline (Fakirhat, Bagerhat) and saline (Chalna, Khulna). Two sunflower varieties such as BARI Sunflower-2 (BARI-52) and Hysun33 and one sunflower line KU-SL-1 were used in the experiment. Just after harvesting of T. Aman rice, sunflower seeds were sown by dibbling method maintaining a line distance of $75 \mathrm{~cm}$ and plant to plant distance of $45 \mathrm{~cm}$. The unit plot size was $4 \mathrm{~m}$ x 5m following Randomized Complete Block Design (RCBD). Seeds were treated with fungicide Vitavex-200 before 24 hours of sowing at the rate of $3 \mathrm{~g} \mathrm{~kg}^{-1}$ seed and were soaked overnight before sowing.

Two seeds were dibbled hill ${ }^{-1}$. After seedling emergence, the vacant hills were filled up by resowing. The manures and fertilizers as recommended by BARI was applied and other intercultural operations were maintained. Salinity level was measured (by electrical conductivity method) for saline soils at vegetative (at 45 DAS), flowering and at harvesting stage and was $6.90,8.15$ and $9.25 \mathrm{dSm}^{-1}$, respectively. Data were recorded from five randomly selected plants from each plot. The collected data were analyzed statistically with the help of a computer program MSTAT-C and the treatment means were compared with Duncan's New Multiple Range Test (DMRT) (Gomez and Gomez, 1984).

\section{Results and Discussion}

\section{Germination}

The genotypes of sunflower had significant effect on seedling emergence in non-saline as well as in saline soil at 5,10,15 and 20 days after sowing (DAS) (Figure 1). In non-saline soil, Hysun-33 showed maximum seedling emergence followed by BARI-S2, while KU-SL-1 produced minimum seedling. In non-saline soil, BARI Sunflower-2 showed quick seedling emergence $(21.02 \%$ at 5 DAS) than other two genotypes. KU-SL-1 had slow rate of seedling emergence in both conditions. Initially (at 5, 10 and 15 DAS) it produced minimum seedling $(2.92,38.60$ and $66.59 \%$, respectively) but finally maximum seedling emergence $(91.11 \%)$, in saline soils, was recorded in this line followed by BARI Sunflower-2 whereas Hysum-33 showed maximum seedling emergence in non-saline condition. This may be due to the slow adjustment of salinity by KU-SL-1 and slow harmful effect of salinity on BARI Sunflower-2 and Hysun-33 in seedling emergence. Mubshar et al. (2012) also found significant variations in days to germination and decreased rate of germination with salinity. 


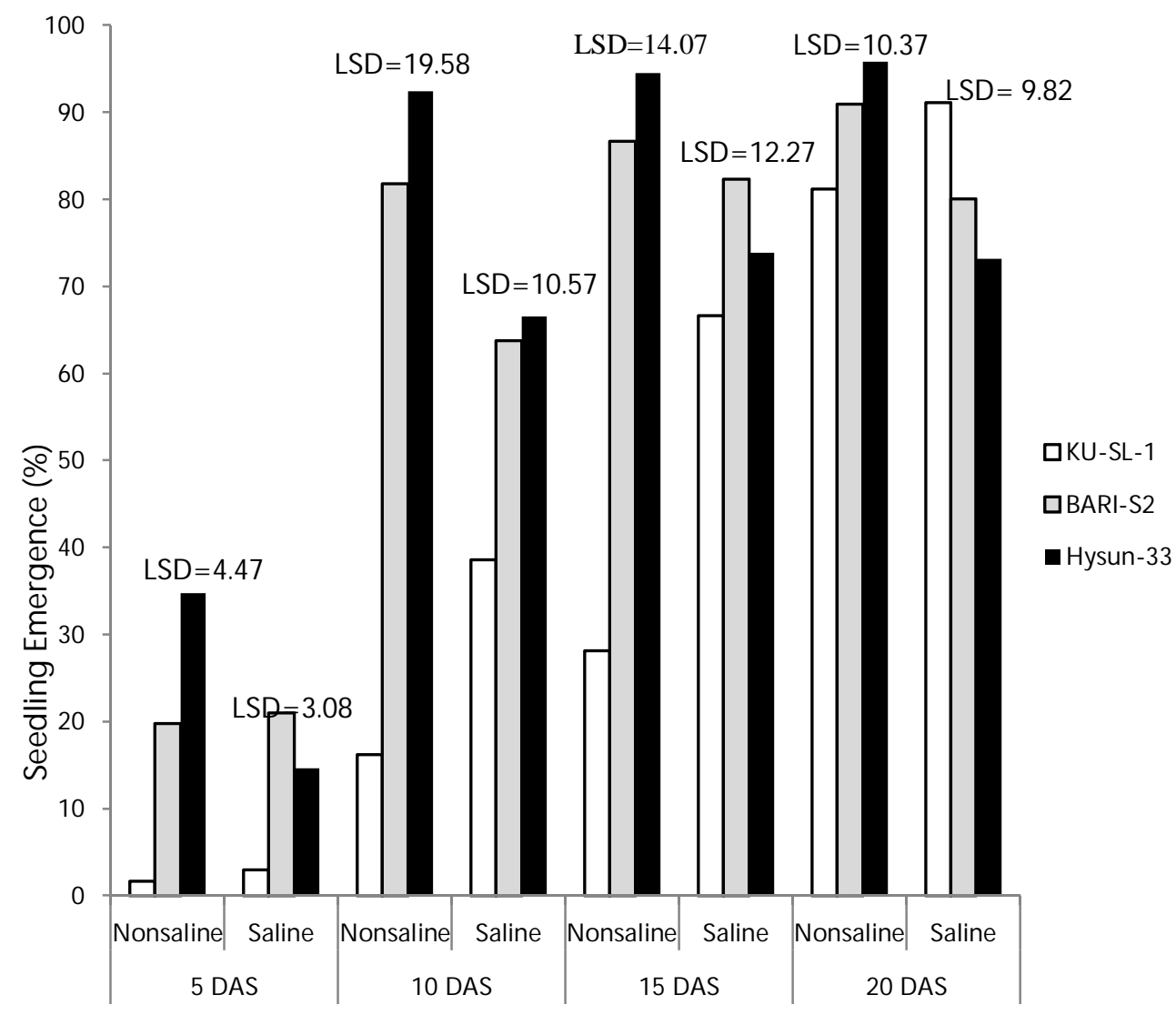

DAS= Days After Sowing; LSD= Least Significant Difference

Figure 1. Emergence (\%) of sunflower seedling in saline and non-saline soil

\section{Growth Parameters}

Genotypic performance of sunflower on plant height at flowering, head diameter at maturity and biomass at harvest varied significantly in both non-saline and saline soils. Variation in leaves plant $^{-1}$ at flowering and stem diameter at maturity was not significant in non-saline soils but significant in saline soils (Table 1). In non-saline soils, plant height varied from 96.55 to 134.68 $\mathrm{cm}$ and in saline soils it was from 77.03 to $99.43 \mathrm{~cm}$. For both saline and non-saline soils, the tallest plant was found in Hysun-33 and the shortest in BARI Sunflower-2. In saline soil, maximum leaves plant ${ }^{-1}$ (22.48) at flowering was found in Hysun-33 and minimum (13.03) in BARI Sunflower-2.The highest stem diameter $(5.49 \mathrm{~cm})$ was found in BARI Sunflower-2 and lowest diameter $(5.10 \mathrm{~cm})$ in KU-SL-1 in non-saline soils but the robust stem $(5.53 \mathrm{~cm})$ was recorded from Hysun-33 and thin stem $(4.19 \mathrm{~cm})$ from BARI Sunflower-2 in saline soils. In both non-saline and saline soils, the largest head (19.03 and $17.06 \mathrm{~cm}$, respectively) was found in Hysun-33 and the smallest head (14.56 and $11.41 \mathrm{~cm}$, respectively) in BARI Sunflower-2. In non-saline soil, maximum biomass accumulation (174.42g) was recorded for KU-SL-1 and that of minimum (38.26g) in BARI Sunflower-2 but in saline soil, highest biomass accumulation (84.12g) was found in Hysun-33 followed by KU-SL-1 and that of lowest (68.35g) in BARI Sunflower-2.

Each and every genotype showed maximum value for most of the tested characters except leaves plant ${ }^{-1}$ in non-saline soils than in saline soils. This may be due to the adverse effect of salinity on growth and development of sunflower plants. Sarwar et al. (2013) was found 
significant differences for plant height among sunflower genotypes. Islam et al. (2008) reported that the number of leaves of sunflower genotypes decreases significantly with salinity. Hanif $e t$ al. (1996) also observed significant differences for stem diameter among sunflower varieties. Escalante et al. (2010) calculated that total biomass of sunflower decreased with increasing salinity.

\section{Yield Parameters}

Total seed, filled seed, weight of filled seed head ${ }^{-1}, 1000$ - seed weight and harvest index $(\%)$ varied significantly with sunflower genotypes in both non-saline and saline soils (Table 2). In both non-saline and saline conditions, total seeds head ${ }^{-1}$ (1246.50 and 1139.50 , respectively) as well as filled (1217.91 and 1024.09, respectively) were highest in Hysun-33 and that of minimum (889.50 and 558.51, respectively; and 824.66 and 498.313, respectively) were produced in BARI Sunflower-2. This may be due to comparatively large head size and small seed size of Hysun-33. In non-saline soils, the highest weight of filled seed head ${ }^{-1}(84.72 \mathrm{~g})$ was found in KU-SL-1 and that of lowest $(52.50 \mathrm{~g})$ in BARI Sunflower-2. But the highest weight of filled seed (65.00 g) was found in Hysun-33 and lowest (42.30 g) in BARI Sunflower-2 in saline soils. Genotypes KU-SL-1 had greater 1000- seed weight (89.40 and 79.34, respectively) in both non-saline and saline soils than the other two genotypes. In non-saline soil, the maximum harvest index $(60.85 \%)$ was calculated for the genotypes BARI Sunflower-2 followed by the genotype Hysun-33 (40.15\%) whereas in saline soil, genotype Hysun-33 showed maximum (43.65\%) harvest index followed by KU-SL-1 (40.28\%). 
Table 1. Growth parameters of sunflower genotypes in saline and non-saline soils

\begin{tabular}{|c|c|c|c|c|c|c|c|c|c|c|}
\hline \multirow[t]{2}{*}{ Genotype } & \multicolumn{2}{|c|}{$\begin{array}{l}\text { Plant height at flowering } \\
(\mathrm{cm})\end{array}$} & \multicolumn{2}{|c|}{$\begin{array}{l}\text { Leaf number at } \\
\text { flowering }\end{array}$} & \multicolumn{2}{|c|}{$\begin{array}{l}\text { Stem diameter at maturity } \\
(\mathrm{cm})\end{array}$} & \multicolumn{2}{|c|}{$\begin{array}{l}\text { Head diameter at maturity } \\
\qquad(\mathrm{cm})\end{array}$} & \multicolumn{2}{|c|}{$\begin{array}{l}\text { Biomass plant }^{-1} \text { at } \\
\text { harvest }(\mathrm{g})\end{array}$} \\
\hline & Non-saline & Saline & Non-saline & Saline & Non-saline & Saline & Non-saline & Saline & Non-saline & Saline \\
\hline KU -SL- 1 & $110.48 \mathrm{~b}$ & $88.20 \mathrm{~b}$ & 15.45 & $16.48 \mathrm{~b}$ & 5.10 & $4.73 \mathrm{~b}$ & $16.03 \mathrm{ab}$ & $14.52 \mathrm{~b}$ & $174.42 \mathrm{a}$ & $73.47 \mathrm{ab}$ \\
\hline BARI -S2 & $96.55 \mathrm{~b}$ & $77.03 \mathrm{c}$ & 16.45 & $13.03 \mathrm{~b}$ & 5.49 & $4.19 \mathrm{c}$ & $14.56 \mathrm{~b}$ & $11.41 \mathrm{c}$ & $38.26 \mathrm{c}$ & $68.35 \mathrm{~b}$ \\
\hline Hysun -33 & $134.68 \mathrm{a}$ & $99.43 \mathrm{a}$ & 17.95 & $22.48 \mathrm{a}$ & 5.38 & $5.53 \mathrm{a}$ & $19.03 \mathrm{a}$ & $17.06 \mathrm{a}$ & $78.75 \mathrm{~b}$ & $84.12 \mathrm{a}$ \\
\hline $\mathrm{CV}(\%)$ & 7.77 & 5.30 & 13.04 & 14.48 & 15.59 & 4.66 & 11.63 & 7.36 & 19.45 & 9.41 \\
\hline LSD (5\%) & 15.31 & 8.09 & NS & 4.34 & NS & 0.39 & 3.33 & 1.83 & 32.69 & 12.26 \\
\hline
\end{tabular}

NS =Not Significant; DAS = Days After Sowing; CV= Coefficient of Variation;

LSD= Least Significant Difference; Values bearing same letter(s) did not differ significantly but with dissimilar letter(s) differ significantly.

Table 2. Effect of saline and non-saline conditions on yield contributing traits of sunflower genotypes

\begin{tabular}{|c|c|c|c|c|c|c|c|c|c|c|}
\hline \multirow[t]{2}{*}{ Genotype } & \multicolumn{2}{|c|}{ Total seeds head ${ }^{-1}$} & \multicolumn{2}{|c|}{ Filled seeds head $^{-1}$} & \multicolumn{2}{|c|}{$\begin{array}{l}\text { Weight of filled seeds } \\
\text { head }^{-1}(\mathrm{~g})\end{array}$} & \multicolumn{2}{|c|}{1000 grain weight $(\mathrm{g})$} & \multicolumn{2}{|c|}{ Harvest Index $(\%)$} \\
\hline & Non-saline & Saline & Non-saline & Saline & Non-saline & Saline & Non-saline & Saline & Non-saline & Saline \\
\hline KU -SL-1 & $961.58 \mathrm{~b}$ & $841.71 b$ & $1115.41 \mathrm{a}$ & $733.92 b$ & $84.72 \mathrm{a}$ & $49.64 \mathrm{~b}$ & $89.40 \mathrm{a}$ & $79.34 \mathrm{a}$ & $32.68 \mathrm{~b}$ & $40.28 \mathrm{ab}$ \\
\hline BARI -S2 & $889.50 \mathrm{~b}$ & $558.51 \mathrm{c}$ & $824.66 \mathrm{~b}$ & $498.313 \mathrm{c}$ & $52.50 \mathrm{~b}$ & $42.30 \mathrm{c}$ & $56.09 \mathrm{~b}$ & $62.64 \mathrm{~b}$ & $60.85 \mathrm{a}$ & $38.30 \mathrm{~b}$ \\
\hline Hysun -33 & $1246.50 \mathrm{a}$ & $1139.50 \mathrm{a}$ & $1217.91 \mathrm{a}$ & $1024.09 \mathrm{a}$ & $52.88 \mathrm{~b}$ & $65.00 \mathrm{a}$ & $56.03 \mathrm{~b}$ & $54.65 \mathrm{~b}$ & $40.15 \mathrm{~b}$ & $43.65 \mathrm{a}$ \\
\hline $\mathrm{CV}(\%)$ & 15.82 & 13.92 & 10.71 & 16.02 & 11.47 & 5.21 & 13.45 & 8.77 & 22.45 & 16.26 \\
\hline $\operatorname{LSD}(5 \%)$ & 282.6 & 203.9 & 195.1 & 208.4 & 12.58 & 4.71 & 15.64 & 9.95 & 17.31 & 4.41 \\
\hline
\end{tabular}

NS =Not Significant; DAS= Days After Sowing; CV= Coefficient of Variation; LSD= Least Significant Difference; Values bearing same letter(s) did not differ significantly but with dissimilar letter(s) differ significantly. 
Each genotype produced maximum value for the tested traits in non-saline soils than that of in saline soils. This may be due to harmful effect of salinity. These findings are in agreement with Sarwar et al. (2013) who found variable performance of sunflower genotypes with variable climatic conditions.

\section{Correlation}

Character association studies indicated that plant height had positive correlation with head diameter. Similar results were reported by Chikkadeviah et al. (2002). For both saline and nonsaline soils, biomass at harvest, total seed head ${ }^{-1}$ and number of filled seed head ${ }^{-1}$ had positive correlation with head diameter and weight of filled seed head ${ }^{-1}$. Among these, biomass at harvest and number of filled seed head ${ }^{-1}$ had relatively greater correlations with weight of filled seed head ${ }^{-1}$ (Table 3). This is in accordance with the reports of Lakshmanaiah (1979) and Dagustu (2002).

Table 3. Correlation between different characters of sunflower genotypes in saline and nonsaline soils

\begin{tabular}{|c|c|c|c|c|c|c|c|c|c|}
\hline & & NLF & $\mathrm{BioH}$ & $\mathrm{PhF}$ & SDm & HDm & $\mathrm{NSH}$ & NFSH & NUSH \\
\hline \multirow{2}{*}{$\mathrm{BioH}$} & NSl & -0.16 & & & & & & & \\
\hline & $\mathrm{Sl}$ & 0.59 & & & & & & & \\
\hline \multirow{2}{*}{$\mathrm{PhF}$} & NSl & 0.37 & 0.09 & & & & & & \\
\hline & Sl & 0.83 & 0.83 & & & & & & \\
\hline \multirow{2}{*}{ SDm } & NSl & 0.59 & -0.09 & 0.19 & & & & & \\
\hline & $\mathrm{Sl}$ & 0.77 & 0.82 & 0.79 & & & & & \\
\hline \multirow{2}{*}{$\mathrm{HDm}$} & $\mathrm{NSl}$ & 0.55 & 0.17 & 0.63 & 0.34 & & & & \\
\hline & Sl & 0.77 & 0.64 & 0.86 & 0.87 & & & & \\
\hline \multirow{2}{*}{ NSH } & $\mathrm{NSl}$ & 0.45 & 0.02 & 0.65 & 0.72 & 0.75 & & & \\
\hline & $\mathrm{Sl}$ & 0.77 & 0.74 & 0.90 & 0.91 & 0.80 & & & \\
\hline \multirow{2}{*}{ NFSH } & $\mathrm{NSl}$ & 0.32 & 0.49 & 0.66 & 0.09 & 0.75 & 0.48 & & \\
\hline & Sl & 0.75 & 0.71 & 0.89 & 0.89 & 0.89 & 0.98 & & \\
\hline \multirow{2}{*}{ NUSH } & NSl & 0.64 & -0.51 & 0.57 & 0.31 & 0.69 & 0.57 & 0.32 & \\
\hline & $\mathrm{Sl}$ & 0.63 & 0.44 & 0.41 & 0.57 & 0.45 & 0.41 & 0.41 & \\
\hline \multirow{2}{*}{ WFSH } & $\mathrm{NSl}$ & -0.30 & 0.86 & 0.01 & -0.11 & 0.13 & 0.04 & 0.21 & 0.68 \\
\hline & Sl & 0.83 & 0.71 & 0.82 & 0.88 & 0.84 & 0.83 & 0.82 & 0.68 \\
\hline
\end{tabular}

Legends: NS $1=$ Non- saline soil, $\mathrm{Sl}=$ Saline soil, $\mathrm{NLF}=$ Number of leaf at flowering, $\mathrm{BioH}=\mathrm{Biomass}$ at harvest, $\mathrm{PhF}=$ Plant height at flowering, $\mathrm{SDm}=$ Stem diameter, $\mathrm{HDm}=$ Head diameter, $\mathrm{NSH}=$ Number of seed head ${ }^{-1}, \mathrm{NFSH}=$ Number of filled seed head ${ }^{-1}, \mathrm{NUSH}=$ Number of unfilled seed head ${ }^{-1}$, WFSH $=$ Weight of filled seed head ${ }^{-1}$.

\section{Conclusion}

For both the saline and non-saline soils, biomass at flowering, number of seed head ${ }^{-1}$, number of filled seed head ${ }^{-1}$ and number of unfilled seed head ${ }^{-1}$ had positive correlation with head diameter and weight of filled seed head ${ }^{-1}$. Among these, biomass at harvest and number of filled seed head $^{-1}(0.75)$ had relatively greater correlations with weight of filled seed head ${ }^{-1}$. Genotype Hysun-33 may be the best for saline and KU-SL-1 for non-saline soils.

\section{References}


Chapman and Carter. 2000. Crop Production Principle and Practices (2nd edn.). Surjeet Publications, Delhi. p.566.

Chapman, S. C., G. L. Hammer and H. Meinke. 1993. A sunflower simulation model I. Model development. Agron. J. 85(3): 725-735.

Chikkadevaiah, H. L., Sujatha and Nandini. 2002. Correlation and path analysis in sunflower. Helia. 25: $109-118$.

Dagustu, N. 2002. Correlation and path coefficient analysis of seed yield components in sunflower (Helianthus annuus L.). Turkish J. of Field Crops. 7: 15-19.

Escalante, A., J. A. Estradaand and M. T. Rodriguez-Gonzalez. 2010. Sunflower biomass distribution and seed yield in saline soil of Mexico highlands. Helia. 33(52): 127-134.

Gomez, K. A. and A. A. Gomez. 1984. Statistical Procedures in Agricultural Research ( $2^{\text {nd }}$ Edn.). Paperback, New York. p. 680.

Gopalan, H. 1982. Nutritive value of Indian foods, Dilhi, India. p. 11.

Hanif, M., Farhatullah and Raziuddin. 1996. Corellation studies of grain yield and other characters in sunflower varieties. Sarhad J. Agric. 12(6): 649-652.

Islam, M., S. Afzal, I. Ahmad, A. Haq and A. Hussain. 2008. Salt tolerance among different sunflower genotype. Sarhad J. Agri. 24(2): 242-250.

Lakshmanaiah, V. H. 1979. Genetic variability and association of morphological characters with seed yield and oil content in sunflower (Helianthus annuus L.). Mysore J. Agri. Sci. 14: 259261.

Mubshar, H., M. Farooq, M. Shehzad, M. B. Khan, A.Wahid and G. Shabir. 2012. Evaluating the performance of elite sunflower hybrids under saline conditions. Int. J. Agric. Biol. 14: 131135.

Sarwar, M. A., M. N. K. Rehman, H. M. R. Javeed, W. Ahmed, M. A. Shehzad and H. T. Abbas. 2013. Comparative performance of various sunflower hybrids for yield and its relative attributes. Cercet Agron Moldova. 4(6): 156 